\title{
Gender Consideration in Sustainable Land Management Project Activities on the Highlands of Kilimanjaro Region: Lessons and Future Outlook
}

\author{
Wakuru Magigi, Allan Sathiel \\ Moshi University College of Cooperative and Business Studies (MUCCoBS), Moshi, Tanzania \\ Email: magigi2000@yahoo.com
}

Received 19 March 2014; revised 19 April 2014; accepted 26 April 2014

Copyright (C) 2014 by authors and Scientific Research Publishing Inc. This work is licensed under the Creative Commons Attribution International License (CC BY). http://creativecommons.org/licenses/by/4.0/

(c) (i) Open Access

\begin{abstract}
The paper contributes on understanding gender considerations into Sustainable Land Management (SLM) project activities on the Highlands of Kilimanjaro Region. Specifically, it documents gender profile and assesses the project activities along with gender considerations, where critical issues, risks and opportunities in relation to gender mainstreaming in SLM project activities are highlighted. It evaluates also the capacity for mainstreaming gender issues into the institutions involved in project implementation. The study employed structured interview and consultative meetings methods with key actors identified. A total of 500 respondents were interviewed in the project catchment areas in the region. Data were analyzed using the Statistical Package for Social Scientists (SPSS). The paper winds up by consolidating key strategic areas for intervention as future outlook and lessons which manifests benchmarks for the Kilimanjaro region to adopt a more programmatic approach to sustainable land management and elsewhere of the same in other cities with the same context in Sub-Saharan Africa.
\end{abstract}

\section{Keywords}

Gender, Sustainable Land Management (SLM), Kilimanjaro, Tanzania

\section{Background}

The Project on Reducing Land Degradation in the Highlands of Kilimanjaro, interchangeably known as Sustainable Land Management (SLM) is being implemented by the Government of Tanzania, with financial support 
from the Government, the Global Environmental Facility (GEF), and the United Nations Development Programme (UNDP). It started in 2010 and officially ends in the year 2014, although there might be a no-cost extension because activity implementation only started in 2012 because of some administrative hurdles.

The project is implemented in seven Districts in the region namely, Rombo, Hai, Siha, Moshi Rural, Moshi Municipality, Mwanga and Same. It covers 40,000 hectares, across six watersheds in three mountains blocks of Kilimanjaro, North Pare and South Pare. The project goal was to ensure Sustainable Land Management, provides a basis for economic development, food security and sustainable livelihoods while restoring the ecological integrity of the Kilimanjaro region's ecosystem. The objective of the project is to provide land users and managers with the enabling environment (policy, financial, institutional, capacity) for SLM adoption with the aims of reducing land degradation in the Kilimanjaro Region. To ensure that the project is gender sensitive, gender mainstreaming is one of the interventions. It ensures project implementation effectiveness, impacts, sustainability and gender relations and their influence on natural resource management and livelihoods productivity.

Gender in this context refers to socially constructed roles, rights, responsibilities and relations existing between men and women [1] [2]. Gender Mainstreaming is a globally accepted strategy for promoting gender equality. It is not an end in itself but a means to achieve the goal of gender equality. It ensures that gender perspectives and attention to the goal of gender equality are central to all activities-policy development, research, advocacy/dialogue, legislation, resource allocation, and planning, implementation and monitoring of programmes and projects [3]. However, to mainstream gender into a project, one needs to analyse the existing gender relations within the project. Such analysis commences with development of a gender profile. Gender profiling, in this context, refers to a process of collecting information towards understanding roles, rights, responsibilities and relations existing between men and women. The profile helps to increase our capacity to gain and maintain a social license to operate, to improve the quality of life and socio-economic conditions of impacted and affected women and men in the communities [4]. Further, it helps to increase local and indigenous employment opportunities, to uphold our commitments to human rights and to minimize the negative impacts of our operations [5].

Despite progress on various initiatives to mainstream women and men in development projects, equality, ownership and use of resources have been minimal in developing countries [2]-[6]. This has resulted into decreasing local economic development, food security, ecological integrity and sustainable livelihoods. Additionally, the effect in low and middle-income countries, is that the labour force participation rate for women remains low and large pay differentials continue to prevail between men and women [7].

\section{Land Degradation Problem in Kilimanjaro Region}

Improper land use leads to land degradation, which in turn leads to a significant reduction in the productive capacity of land. Human activities contributing to land degradation include land-use change, poor land-management practices, deforestation, and unsustainable harvesting of natural resources. Others include rapid population increase, declining commodity prices, and climate change. Natural disasters, including drought, floods and landslides also contribute to land degradation in Kilimanjaro region and elsewhere in Tanzania and other countries [8]-[10]. Examples of land degradation include completely deforested patches and serious erosion gullies that are common in the region. The project is therefore a response to the fact that despite its local and global significance, the Kilimanjaro ecosystem is experiencing extensive degradation and deforestation, driven by this set of complex interrelated factors which affect sustainable land management in the Kilimanjaro region. Considering that the human activities are done by both men and women, this further justification for gender be mainstreamed into the project.

\section{Study Approach and Methods}

\subsection{Description of the Study Area}

The study was conducted in seven Districts of Kilimanjaro region as previously stated. According to the Tanzania National Housing and population census report (1967-2012), Kilimanjaro region has an area of 13,209 sq. $\mathrm{km}$. Her population had increased from 652,724 in 1967 to 1,640,087 in 2012 within the same area. The population is made up of 793,140 men and 842,934 women. With a land area of 13,209 sq. km the population density of Kilimanjaro has increased from 68 person per sq. km. in 1978 to 84 persons per sq. km. in 1988. It has further increased form 104 in 2002 to 124 persons per sq. $\mathrm{km}$ in 2012 [11]. This rapid population density increase imposes 
different challenges in terms of food security and regions ecosystem conservation. The population increase has affected land use patterns in the region manifested by increased land subdivisions for housing, agriculture, recreational and other livelihood activities including gardening. The increased population is coupled with high dependence on agriculture for economic activities, which leads to land defragmentation. Other problems emanating from increased population density is concentration of economic activities and failure to practice sustainable land use measures that has affected the ecological stability of the region. These problems have resulted to decreased farm productivity, declining production quality and consequently low income. This analysis of the demography of the region implies that labour force comprises women mainly. As such, any project that ignores women, is excluding a good proportion of the labour force.

\subsection{The Study Approach and Tools}

The study employed multi-staged approach, where a series of steps were followed during its implementation. These include an inception meeting, documentary review, data collection and report writing as explained hereunder:

\subsubsection{Stage 1: Inception Meeting}

This stage was meant for designing the road map for study execution and sharing understanding of the assignment. The consultant prepared an inception report, which before final submission and presentation was reviewed by Project Coordination Unit (PCU) and later it was presented at workshop, which was attended by different stakeholders. Relevant comments from stakeholders were taken on board and final inception report was produced and submitted to the client.

\subsubsection{Stage 2: Documentary Review and Study Instruments Preparation}

During this stage, a preliminary gender profile of project catchment was developed based in Harvard Gender Analysis Framework, which takes into consideration productive/livelihood activities for women and men, roles and relationship between men and women, access to benefits and control of resources. Project activities were identified in each district project catchment areas as per planned schedule of work. Research instruments, including a questionnaire were prepared and reviewed by the Project Coordination Unit (PCU).

Use of a questionnaire was preferred to other methods because it was considered to be more appropriate than other techniques, for example the Rapid Rural Appraisal (RRA) and Participatory Rural Appraisal (PRA) [12] because it can be administered randomly, thereby taking into account stratification within a community, be it by wealth, social status, gender or ethnic group. The findings are, therefore, more statistically sound than those from PRA and RRA, because the latter are often carried out with the community as a whole thereby obscuring the extant stratification [12]. A structured and open-ended questionnaire, therefore, was prepared. The questionnaire was structured into two parts; Part one aimed at collecting respondent's demographic characteristics and socio-economic setting. The second part centered on collecting data based on the themes as per terms of references. The structured questions were employed on issues where a specific range of known responses was expected. Such questions allow easier interpretation and analysis than open-ended questions. On the other hand, the open-ended questions were included so as to allow interviewees to construct their own accounts of experiences because the explanatory power of structured questions is limited [13].

\subsubsection{Stage 3: Data Collection, Analysis, Interpretation and Interim Report Production Stage}

The research instruments prepared were tested during pilot study and some adjustments were made. Before embarking to data collection tasks, the study areas were selected with assistance from District Focal Persons. Later, the District Focal Persons for the Project were contacted for fieldwork activity and the schedules of the interview were made. The consultant in collaboration with District Facilitating Teams identified actors in project catchment areas to be involved in the study. Communications were done with SLM districts focal persons for arrangement of data collection in project catchment areas.

A total of 500 respondents were approached for interview in which 243 were female, the rest were men (Table 1). Data collection processes in each district were administered by five enumerators with a team leader. The enumerators were selected based on their conversant with both Kiswahili and English languages and experience with field work within Kilimanjaro region. 
Table 1. Number of respondents categorized by gender in project catchment areas.

\begin{tabular}{|c|c|c|c|c|c|c|c|c|c|c|c|c|c|c|}
\hline \multirow{4}{*}{ Target group } & \multicolumn{14}{|c|}{ Regional districts and her project catchment areas } \\
\hline & \multirow{2}{*}{\multicolumn{2}{|c|}{$\begin{array}{c}\text { Rombo } \\
\begin{array}{c}\text { Ibukoni } \\
\text { catchment }\end{array}\end{array}$}} & \multirow{2}{*}{\multicolumn{2}{|c|}{$\begin{array}{c}\text { Siha } \\
\begin{array}{c}\text { Lawate } \\
\text { catchment }\end{array}\end{array}$}} & \multirow{2}{*}{\multicolumn{2}{|c|}{$\begin{array}{l}\text { Moshi DC } \\
\text { Rau Forest }\end{array}$}} & \multirow{2}{*}{\multicolumn{2}{|c|}{$\begin{array}{l}\text { Moshi MC } \\
\text { Rau Forest }\end{array}$}} & \multirow{2}{*}{\multicolumn{2}{|c|}{$\begin{array}{c}\text { Same } \\
\begin{array}{c}\text { Vunta } \\
\text { mabilioni }\end{array}\end{array}$}} & \multicolumn{2}{|c|}{ Mwanga } & \multicolumn{2}{|c|}{ Hai } \\
\hline & & & & & & & & & & & Butu c & hment & $\begin{array}{r}\mathrm{Ki} \\
\mathrm{catc}\end{array}$ & nent \\
\hline & M & $\mathrm{F}$ & M & $\mathrm{F}$ & M & $\mathrm{F}$ & M & $\mathrm{F}$ & M & $\mathrm{F}$ & M & $\mathrm{F}$ & M & $\mathrm{F}$ \\
\hline Households & 27 & 25 & 24 & 31 & 33 & 24 & 27 & 31 & 30 & 17 & 29 & 25 & 19 & 28 \\
\hline CBOs members & 6 & 10 & 8 & 4 & 6 & 10 & 9 & 3 & 5 & 15 & 4 & 8 & 15 & 5 \\
\hline Agricultural extension officers & & & 1 & & & 1 & & 1 & 1 & & & 1 & & \\
\hline WEO and VEO & & & 1 & & & 1 & & & & 1 & 1 & 2 & 1 & \\
\hline Councillors & & & & & & & & & & & 1 & & & \\
\hline Regional Secretariat & & & & & & & 1 & & & & & & & \\
\hline $\begin{array}{l}\text { Pangani Natural Resource } \\
\text { Conservation Institutions }\end{array}$ & & & & & & & 1 & & & & & & & \\
\hline District Facilitative Teams & 1 & & 1 & & & 1 & & 1 & 1 & & 1 & & 1 & \\
\hline Total & 34 & 35 & 35 & 35 & 39 & 37 & 38 & 36 & 37 & 33 & 36 & 36 & 36 & 33 \\
\hline
\end{tabular}

*WEO = Ward Executive Officers, VEO = Village Executive Officers, DFTs = District Facilitating Teams, MC = Municipal Council, DC = District Council.

Training to enumerators was done before pre-field work testing of questionnaires and subsequently interpretation of data collected. The use of Kiswahili and English language in administering the questionnaires aims to enhance respondents' flexibility in responding to questions asked and free to provide information. Data were analysed through an application of both qualitative and quantitative techniques. Quantitative data were analysed through the application of the Statistical Package for Social Sciences (SPSS) and Microsoft Excel. Qualitative data were analysed as per number of themes explored namely context analysis. Findings are presented in the form of tables, graphs, percentages and frequency distributions.

\subsubsection{Stage 4: Stakeholders' Workshop and Final Report Production}

This is the last stage which requires the consultant to submit the interim report, which will be presented to another stakeholders' workshop. Relevant comments from the workshop will be compiled and the final report prepared and submitted to the client.

\subsection{Study Limitation and Delimitation}

During the field work, enumerators faced various challenges including low cooperation of some respondents to provide required data in time, non-accessibility of respondents especially who are working in remote areas including Moshi Municipality. In certain incidents the enumerators faced difficulties in locating Community Based Organisations members and households in project catchment areas. This was to remoteness of CBO members and some households' residence areas, where transport facility were difficult to reach. It was found also that most CBOs have no permanent location or offices; as a result the consultant had to use more time to find these actors especially during the fieldwork stage. In order to deal with challenges, the following were undertaken;

1) The DFTs were instructed by enumerators to inform and organise the missing Community Based Organisations members and households respondents in project catchment areas for interviews during the weekends;

2) District Facilitating Team members introduced the enumerators to institutions implementing the SLM activities including CBOs members and Households during the interview session in their respective districts. This enabled easy access and collection of data;

3) Using telephone to locate the respondents. 


\section{Findings and Discussions}

This section provides an interpretation of the results arising from the assessment of the gender profile of the project area, project activities along with gender consideration, and capacity of institutions involved in project implementation to mainstream gender in their organizations. Further, the section discusses traditional institutions in relation to natural resource management and associated issues and challenges.

\subsection{Gender Profile for the Project Catchment Areas}

\section{Activities Done by Men and Women}

The study shows that both men and women in project catchments areas are involved in different productive and domestic activities towards sustaining their livelihood (Table 2). Some of the activities are dominated by men, while others by women. Arts and crafts are among the activities that are dominated by women (Table 2). Selling goods in the market such as banana and other agro-products has also high percentage of women dominance. Other are, to a large extent, done by both men and women. Domestic livelihood activities are also mainly dominated by women. Activities like food preparation are dominated by women which occupy 168 (75.3\%) of the total respondents. Other domestic activities namely collecting fuel wood, fetching water, child care and cleaning houses are also dominated by women. The rest are dominated by men. The reason provided for other activities having higher percentage of men than women is the nature of the work that require masculinity. For example terracing and building houses works.

From the gender profile presented in Table 2, it can be deduced that productive livelihood activities, though at varying degree, are the responsibility of both men and women, but domestic livelihood activities are dominated by women, including collecting fuel woods and cooking for the family.

Despite increased economic role and recognition of women, their values and contribution to family livelihood activities have not gained leadership membership in the traditional institutions that involved in decision making for natural resource management activities. Thus, capacity building in terms of mainstreaming gender is vital for

Table 2. Gender profile in SLM project catchment areas in Kilimanjaro region.

\begin{tabular}{|c|c|c|c|c|c|c|c|c|c|c|c|c|c|c|c|c|c|c|c|c|c|c|c|c|}
\hline \multirow{2}{*}{$\begin{array}{l}\text { Productive } \\
\text { livelihood } \\
\text { activities }\end{array}$} & \multirow{2}{*}{\multicolumn{3}{|c|}{$\begin{array}{c}\text { Rombo } \\
\begin{array}{c}\text { Ibukoni } \\
\text { catchment }\end{array}\end{array}$}} & \multirow{2}{*}{\multicolumn{3}{|c|}{$\begin{array}{c}\text { Siha } \\
\begin{array}{c}\text { Lawate } \\
\text { catchment }\end{array}\end{array}$}} & \multirow{2}{*}{\multicolumn{3}{|c|}{$\begin{array}{l}\text { Moshi DC } \\
\begin{array}{l}\text { Rau Forest } \\
\text { catchment }\end{array}\end{array}$}} & \multirow{2}{*}{\multicolumn{3}{|c|}{$\begin{array}{l}\text { Moshi MC } \\
\begin{array}{l}\text { Rau Forest } \\
\text { catchment }\end{array}\end{array}$}} & \multirow{2}{*}{\multicolumn{3}{|c|}{$\begin{array}{c}\text { Same } \\
\text { Vunta mabilioni } \\
\text { catchment }\end{array}$}} & \multirow{2}{*}{\multicolumn{3}{|c|}{$\begin{array}{c}\text { Mwanga } \\
\text { Butu catchment }\end{array}$}} & \multirow{2}{*}{\multicolumn{3}{|c|}{$\begin{array}{c}\text { Hai } \\
\text { Kikafu catchment }\end{array}$}} & \multirow{2}{*}{\multicolumn{3}{|c|}{ Total }} \\
\hline & & & & & & & & & & & & & & & & & & & & & & & & \\
\hline i. Crop farming & 7 & 2 & 50 & 5 & 2 & 52 & 7 & 1 & 56 & 5 & 1 & 30 & 6 & 3 & 60 & 7 & 2 & 59 & 6 & 1 & 61 & 43 & 12 & 368 \\
\hline $\begin{array}{l}\text { ii. Livestock } \\
\text { keeping }\end{array}$ & 3 & 2 & 28 & 2 & 2 & 29 & 2 & 1 & 19 & 2 & 1 & 15 & 1 & 2 & 26 & 3 & 2 & 29 & 3 & 2 & 27 & 16 & 12 & 173 \\
\hline iii. Beekeeping & 0 & 6 & 11 & 0 & 7 & 12 & 0 & 7 & 12 & 0 & 6 & 11 & 0 & 5 & 11 & 0 & 7 & 13 & 0 & 7 & 13 & 0 & 35 & 93 \\
\hline iv. Business & 2 & 0 & 12 & 2 & 0 & 11 & 1 & 0 & 12 & 1 & 0 & 13 & 2 & 0 & 12 & 2 & 0 & 11 & 1 & 0 & 12 & 11 & 0 & 81 \\
\hline v. Arts and crafts & 16 & 0 & 15 & 18 & 0 & 14 & 20 & 0 & 16 & 16 & 0 & 16 & 18 & 0 & 15 & 17 & 0 & 13 & 18 & 0 & 16 & 123 & 0 & 105 \\
\hline vi. Tree planting & 2 & 0 & 22 & 1 & 0 & 24 & 2 & 0 & 24 & 1 & 0 & 20 & 2 & 0 & 26 & 1 & 0 & 24 & 3 & 0 & 28 & 12 & 0 & 168 \\
\hline $\begin{array}{l}\text { vii. Building } \\
\text { houses }\end{array}$ & 0 & 5 & 5 & 0 & 6 & 5 & 0 & 7 & 5 & 0 & 7 & 6 & 0 & 8 & 5 & 0 & 7 & 7 & 0 & 7 & 7 & 0 & 52 & 35 \\
\hline $\begin{array}{l}\text { viii. Selling goods } \\
\text { in the markets }\end{array}$ & 6 & 0 & 15 & 7 & 0 & 18 & 6 & 0 & 16 & 8 & 0 & 17 & 5 & 0 & 21 & 7 & 0 & 17 & 4 & 0 & 15 & 43 & 0 & 119 \\
\hline $\begin{array}{l}\text { Domestic } \\
\text { Livelihood } \\
\text { Activities }\end{array}$ & & & & & & & & & & & & & & & & & & & & & & & & \\
\hline $\begin{array}{l}\text { i. Fetching } \\
\text { Fuel wood }\end{array}$ & 13 & 0 & 19 & 14 & 0 & 20 & 12 & 0 & 18 & 8 & 0 & 16 & 13 & 0 & 19 & 12 & 0 & 21 & 11 & 0 & 18 & 83 & 0 & 131 \\
\hline ii. Fetching water & 16 & 0 & 15 & 17 & 0 & 19 & 17 & 0 & 19 & 9 & 0 & 10 & 19 & 0 & 12 & 17 & 0 & 17 & 15 & 0 & 18 & 110 & 0 & 110 \\
\hline iii. Child care & 1 & 10 & 22 & 1 & 9 & 20 & 1 & 7 & 23 & 1 & 8 & 21 & 1 & 11 & 22 & 0 & 8 & 19 & 1 & 9 & 25 & 6 & 62 & 152 \\
\hline $\begin{array}{l}\text { iv. Food } \\
\text { preparation }\end{array}$ & 24 & 0 & 6 & 26 & 0 & 7 & 24 & 0 & 8 & 22 & 0 & 7 & 24 & 0 & 9 & 23 & 0 & 10 & 25 & 0 & 7 & 168 & 0 & 54 \\
\hline $\begin{array}{l}\text { v. Cleaning } \\
\text { houses }\end{array}$ & 18 & 0 & 10 & 20 & 0 & 11 & 21 & 0 & 9 & 20 & 0 & 10 & 23 & 0 & 13 & 19 & 0 & 11 & 23 & 0 & 14 & 144 & 0 & 78 \\
\hline
\end{tabular}

${ }^{*} \mathrm{~W}=$ Women, $\mathrm{M}=$ Men, $\mathrm{W} \& \mathrm{M}=$ Women and Men. 
enhancing SLM project activities implementation for reducing poverty at family levels in project catchment areas.

As far as the land degradation control is concerned, the study found that it is a responsibility of both men and women in all production activities undertaken on land. The results from the survey show that there are five activities that are done by men and women for reducing land degradation. These activities are terracing, crop rotation, afforestation and reforestation, water sources conservation and construction of surface run-off barriers. Among these activities found, respondents (Table 3) revealed that there is no exception; both men and women to participate in these activities since everyone in the community practice such activities.

\subsection{Project Activities and Role of Women and Men in SLM Activities}

Involvement in project activities (Table 4) by gender follows the profile described earlier on. This result gives confidence in the profile that has been developed.

Among these activities, respondents revealed that there is no difference for men or women to participate in these activities since everyone in the community undertakes such activities. Few respondents (3\%) of the total (48) reported that since terracing is a hard work it has to be performed by men but the majority consider it as not a gender specific activity. Conserving water sources in the project catchment areas was considered to be men centred activity primarily due to its association with cultural belief that women are not allowed to enter in water sources with the belief that the source will dry up.

Gender relationship and participation between men and women in the SLM project activities implementation differs from one catchment area to another in the region. Where women work separately with men, harmony is highly achieved for example Women in Mwanga District argue that men want immediate success in terms of income earning. As such, shows that in operating the group slow success of income earning and distribution of benefits are gradual. This has been also observed in the traditional institutions where both men and women work together in implementing project activities and other livelihood activities. Thus, building, formalising and

Table 3. Number of responses for specific activities for controlling land degradation.

\begin{tabular}{ccc}
\hline Activities & Men & Both men and women \\
Terracing & 14 & 464 \\
Crop rotation & 0 & 478 \\
Afforestation and reforestation & 14 & 459 \\
Water sources conservation & 19 & 468 \\
\hline
\end{tabular}

Table 4. Activities done by SLM project with gender perspectives in the project catchment areas.

\begin{tabular}{|c|c|c|c|c|c|c|c|c|c|c|c|c|c|c|}
\hline \multirow{3}{*}{ Target Group } & \multicolumn{2}{|c|}{ Rombo } & \multicolumn{2}{|c|}{ Siha } & \multicolumn{2}{|c|}{ Moshi DC } & \multicolumn{2}{|c|}{ Moshi MC } & \multicolumn{2}{|c|}{ Same } & \multicolumn{2}{|c|}{ Mwanga } & \multicolumn{2}{|c|}{ Hai } \\
\hline & \multicolumn{2}{|c|}{ Ibukoni catchment } & \multicolumn{2}{|c|}{$\begin{array}{c}\text { Lawate } \\
\text { catchment }\end{array}$} & \multicolumn{2}{|c|}{$\begin{array}{l}\text { Rau Forest } \\
\text { catchment }\end{array}$} & \multicolumn{2}{|c|}{$\begin{array}{l}\text { Rau Forest } \\
\text { catchment }\end{array}$} & \multicolumn{2}{|c|}{$\begin{array}{l}\text { Vunta } \\
\text { mabilioni }\end{array}$} & \multicolumn{4}{|c|}{ Butu catchment Kikafu catchment } \\
\hline & M & $\mathrm{F}$ & M & $\mathrm{F}$ & M & $\mathrm{F}$ & M & $\mathrm{F}$ & M & $\mathrm{F}$ & M & $\mathrm{F}$ & M & $\mathrm{F}$ \\
\hline Supporting CBOs & 4 & 5 & 7 & 8 & 6 & 6 & 5 & 5 & 6 & 7 & 4 & 6 & 5 & 6 \\
\hline Planting trees & 10 & 10 & 15 & 14 & 12 & 11 & 12 & 12 & 10 & 10 & 10 & 10 & 12 & 12 \\
\hline $\begin{array}{c}\text { Education related to } \\
\text { environment }\end{array}$ & 8 & 10 & 9 & 6 & 7 & 9 & 9 & 9 & 9 & 7 & 6 & 9 & 10 & 8 \\
\hline Sensitization on terracing & 4 & 3 & 3 & 4 & 5 & 4 & 3 & 4 & 4 & 2 & 3 & 3 & 3 & 3 \\
\hline Increased social network & 3 & 3 & 3 & 4 & 2 & 2 & 3 & 4 & 3 & 4 & 2 & 4 & 2 & 2 \\
\hline $\begin{array}{l}\text { Facilitating formation of } \\
\text { community groups }\end{array}$ & & & & 1 & & & & & & & 1 & 1 & & 1 \\
\hline Total & 29 & 31 & 37 & 37 & 32 & 32 & 32 & 34 & 32 & 30 & 26 & 33 & 32 & 32 \\
\hline
\end{tabular}


strengthening gender relation and ensure participation are vital in ensuring SLM project effectiveness and sustainability.

\subsubsection{Access to Benefit and Control of Productive Activities}

Access to benefits from productive livelihood activities and resources is an important element for mainstreaming gender in SLM activities. It takes consideration on a situation of who has greater benefit over the livelihood activities and other resources. The study shows that men and women have unequal benefit to productive livelihood activities. It shows that men benefit more in ownership of resources (133) of the interviewed respondents. These findings suggest that there is disparity in resource ownership and control of resources to both women and men. The reason provided as to why men have greater benefit to resource ownership are due to strong attachment to customs and traditional system, which limit equal access to resources and control of farm and non-farm activities at family level. For example, it was found that household assets belongs to the father particularly land and other tangibles. As such, a girl child is not entitled to inherit land as she is expected to be married away while the boy is entitled to own the same resource. This contradicts with country policy and regulations on land development which recognise the right of both men and women to access, use, control and own land resources [14]. Other benefits found include access to basic needs, access to education and social network as showing in Table 5 .

\subsubsection{Specific Needs of Men and Women}

The study revealed specific needs for men and women participating in land degradation project implementation. Environmental education for both men and women is the most critical need element reported by 115 of the households and CBOs respondents interviewed (Table 6). Likewise, working facilities including special wear in activities like bee-keeping for men and women to enable effective working environment are important. Currently, men are the only ones dominating the bee-keeping activity although women are able and willing to participate. The reason of discriminating women from beekeeping are strong attachment to traditional culture and believes, which states that, once women visit beekeeping hives, honey will not be available. The investigators were not able to prove this argument beyond doubt, but women mentioned this as a bottleneck to their participation in beekeeping. Further, some of the need of households were different from the needs of the CBOs, for example while the household insist on the need of market for their product, the CBOs members in the project catchment areas require working gears and finance to facilitate their activities. Thus, training both CBOs and households on the use of the benefits of SLM program outcomes is important for increasing their productivity.

Other needs required for mainstreaming gender in SLM project activities include financial support and markets for their products to both women and men. However, the study revealed some complains, groups involved in water sources conservation where incentives were not given. They point out that if certain amount of incentives in terms of finance support is provided then they will be motivated and improve their land and enhance their level of productivity and environmental conservation (Table 6).

Table 5. Access to benefits of productive livelihood activities.

\begin{tabular}{|c|c|c|c|c|c|c|c|c|c|c|c|c|c|c|}
\hline \multirow{3}{*}{ Target group } & \multirow{2}{*}{\multicolumn{2}{|c|}{$\begin{array}{c}\text { Rombo } \\
\text { Ibukoni } \\
\text { catchment }\end{array}$}} & \multirow{2}{*}{\multicolumn{2}{|c|}{$\begin{array}{c}\text { Siha } \\
\begin{array}{c}\text { Lawate } \\
\text { catchment }\end{array}\end{array}$}} & \multirow{2}{*}{\multicolumn{2}{|c|}{$\begin{array}{c}\text { Moshi DC } \\
\begin{array}{c}\text { Rau Forest } \\
\text { catchment }\end{array}\end{array}$}} & \multirow{2}{*}{\multicolumn{2}{|c|}{$\begin{array}{c}\text { Moshi MC } \\
\text { Rau Forest } \\
\text { catchment }\end{array}$}} & \multirow{2}{*}{\multicolumn{2}{|c|}{$\begin{array}{c}\text { Same } \\
\text { Vunta } \\
\text { mabilioni }\end{array}$}} & \multicolumn{2}{|c|}{ Mwanga } & \multicolumn{2}{|c|}{ Hai } \\
\hline & & & & & & & & & & & Butu & hment & $\begin{array}{r}\mathrm{K} \\
\text { cat }\end{array}$ & \\
\hline & M & $\mathrm{F}$ & M & $\mathrm{F}$ & M & $\mathrm{F}$ & M & $\mathrm{F}$ & M & $\mathrm{F}$ & M & $\mathrm{F}$ & M & $\mathrm{F}$ \\
\hline Income increase & 16 & 16 & 15 & 14 & 21 & 18 & 19 & 13 & 17 & 19 & 20 & 17 & 16 & 17 \\
\hline $\begin{array}{l}\text { Increased access } \\
\text { to basic needs }\end{array}$ & 16 & 16 & 18 & 15 & 19 & 19 & 15 & 18 & 16 & 18 & 18 & 17 & 17 & 16 \\
\hline Access to education & 17 & 16 & 18 & 17 & 19 & 18 & 16 & 19 & 16 & 15 & 18 & 16 & 16 & 17 \\
\hline $\begin{array}{l}\text { Improved ownership of } \\
\text { resources }\end{array}$ & 15 & 14 & 23 & 15 & 18 & 13 & 20 & 17 & 18 & 12 & 20 & 18 & 19 & 16 \\
\hline Increased social network & 15 & 15 & 19 & 18 & 18 & 16 & 19 & 17 & 17 & 18 & 18 & 14 & 17 & 17 \\
\hline Total & 79 & 77 & 93 & 79 & 95 & 84 & 89 & 84 & 84 & 82 & 94 & 82 & 85 & 83 \\
\hline
\end{tabular}


Table 6. Specific and gender needs for mainstreaming gender in SLM activities.

\begin{tabular}{|c|c|c|c|c|c|c|c|c|c|c|c|c|c|c|}
\hline \multirow{3}{*}{ Needs for SLM implementation } & \multicolumn{2}{|c|}{ Rombo } & \multicolumn{2}{|c|}{ Siha } & \multicolumn{2}{|c|}{ Moshi DC } & \multicolumn{2}{|c|}{ Moshi MC } & \multicolumn{2}{|c|}{ Same } & \multicolumn{2}{|c|}{ Mwanga } & \multicolumn{2}{|c|}{ Hai } \\
\hline & & & & & $\begin{array}{l}\text { Rau } \\
\text { catc }\end{array}$ & $\begin{array}{l}\text { rest } \\
\text { ent }\end{array}$ & $\begin{array}{l}\text { Rau } \\
\text { catc }\end{array}$ & $\begin{array}{l}\text { orest } \\
\text { nent }\end{array}$ & & & Butu & Iment & $\begin{array}{r}\mathrm{K} \\
\text { catc }\end{array}$ & afu \\
\hline & $\mathrm{M}$ & $\mathrm{F}$ & $\mathrm{M}$ & $\mathrm{F}$ & $\mathrm{M}$ & $\mathrm{F}$ & $\mathrm{M}$ & $\mathrm{F}$ & $\mathrm{M}$ & $\mathrm{F}$ & $\mathrm{M}$ & $\mathrm{F}$ & $\mathrm{M}$ & $\mathrm{F}$ \\
\hline $\begin{array}{c}\text { Education on } \\
\text { environmental issues }\end{array}$ & 9 & 9 & 7 & 9 & 9 & 6 & 9 & 10 & 7 & 8 & 6 & 7 & 10 & 9 \\
\hline Working facilities & 5 & 7 & 5 & 8 & 6 & 6 & 4 & 8 & 5 & 7 & 6 & 5 & 7 & 9 \\
\hline Market for their produces & & 1 & & 2 & 1 & & 1 & 1 & & 1 & 1 & & 1 & 2 \\
\hline Financial support & 2 & 2 & 2 & 2 & 2 & 1 & 1 & 3 & 1 & 2 & 1 & 3 & 2 & 2 \\
\hline Total & 16 & 19 & 14 & 21 & 18 & 13 & 15 & 20 & 13 & 18 & 14 & 15 & 19 & 22 \\
\hline
\end{tabular}

\subsection{Capacity for Mainstreaming Gender Issues in the Institutions Implementing the Project}

The capacity of institutions to mainstream gender was assessed based on five parameters. These are; Staff Qualification in Terms of Education, Staff with knowledge and training in gender issues and related policies, Staff with Gender mainstreaming skills, Inclusion of gender into normal routine of an institution and allocation of Budget for Gender Related Activities. The findings show that the capacity of institutions implementing the project to mainstream gender differs in different parameters as explained herein.

\subsubsection{Staff Qualification in Terms of Education with Gender Skills}

Staff qualification was measured in terms of area of specialisation and the purpose was to determine whether there are staffs who have knowledge or have at least studied subjects related to gender issues. Findings show that 54 members of District Facilitative Teams (DFTs) are from different areas of specialisation (Table 7) including Agriculture, forestry, land surveying, planning, economics, community development and social welfare and veterinary science. Other fields include human nutrition, range management, land use and law. In this context most staffs have not formal knowledge in gender issues with exception of those who have specialized in community development, planning and gender and social welfare. In all seven districts there is at least one staff who have qualification in community development which include studies related to gender as portrayed by the respondents during interview. In this respect issues related to gender can be dealt with in the DFT with assistance from community development specialist.

\subsubsection{Staff with Knowledge and Other Training in Gender Issues}

In each district team there are at least one staff with knowledge and training in gender issues and related policies. Among 59 staff involved in SLM project activities from Regional Project Coordination Unit, District Facilitative Teams and representative from Pangani Water Basin Conservation, only 14 staff has knowledge and have received other training in gender issues. This implies that in case there are activities that require participation of men and women and facilitation is a demand these staff can play their role though they are not enough to cover all the areas where the project is implemented provided that gender mainstreaming is among the pertinent issues to deal with in the communities. The knowledge can be shared among the staffs and in collaboration with other staff they can implement gender related issues. In this regard it can be noted that there is a gap in terms of knowledge and ability to mainstream gender among institutions implementing the project due to inadequacy of number of staffs.

\subsubsection{Staff with Gender Mainstreaming Skills}

Gender mainstreaming in SLM project activities requires more than just having knowledge in gender and its related policies, more emphasis is needed on mainstreaming skills. In this respect it has been found that among 59 staff in implementing institutions only 3 staff (from Same district, Mwanga district and within Project Coordination Unit) have staffs who have gender mainstreaming skills (Refer Table 7). This indicates that main 
Table 7. Capacity of institutions to mainstream gender.

\begin{tabular}{llll}
\hline Institution & Staff qualification in terms of education & $\begin{array}{l}\text { Staff with knowledgeStaff with } \\
\text { and training in } \\
\text { gender issues and } \\
\text { related policies }\end{array}$ & $\begin{array}{l}\text { Gender mainstreaming into normal routine } \\
\text { skills }\end{array}$ \\
& & $\begin{array}{l}\text { Related } \\
\text { Activities }\end{array}$
\end{tabular}

District Councils

1 Diploma in Forestry

1 Diploma in Land use

1 staff has diploma in community

Mwanga development and gender

1 Diploma in planning and gender

1 Advanced Diploma in Planning

1 Diploma in Range management

1 Diploma in Agro mechanics

1 Bachelor Degree in Agricultural Engineering

2 Bachelor Degree in Veterinary Science

1 Postgraduate Diploma in Community

Moshi Rural Development

1 Diploma in Forestry

1 Diploma in Land Survey

2 Diploma in Land Use

1 BA-Community Economic Development

1 BSc. Human Nutrition

Moshi 1 MA-Cooperative and Community Development

Municipal 1 Master Degree in Economics

1 Bachelor in Town Planning

1 Certificate in Forestry

1 Advanced Diploma in Land Survey

Rombo

2 Bachelor degrees

6 Diploma

1 Degree in Forestry

1 Degree in Environmental Science

1 Certificate in Community Development

1 Bachelor Degree in Social Work

1 Bachelor Degree in Land Survey

1 Bachelor Degree in Economics

1 Bachelor Degree in Veterinary Science

1 MSc. Community Economic Development

1 Bachelor Degree in Horticulture

1 Bachelor Degree in Agribusiness

1 Diploma in Agriculture

Siha

1 Bachelor of Laws

1 Advanced Diploma in Community

Development and Gender

1 Diploma in Land Management

1 Bachelor Degree in Veterinary Science

2 Master degrees

$\mathrm{Hai}$

2 Post graduate diploma

1 Advanced Diploma in Community Development 4 Staffs

1 Bachelor in Land Valuation

Pangani River
Water Basin

1 Engineer (Hydrologist Interviewed)

4 SLM Project Coordination Unit staffs

Regional

Project

interviewed and supervising SLM

activities in the region
1 Staff

3 Staffs

2 Staff 1 staff

1 Staff

Non

1 Staff

Non

Non

1 Staff

Non

Non

Men and women are involved in group No Budget activities and allocated trainings

Men and women involved in group No Budget activities and training allocated

Women and men

emphasized

No Budget

particularly in group

allocated

activities

Men and women are

considered in daily No Budget

project

allocated

Men and women are considered in daily No Budget project allocated

activities

Involved in group No Budget activities and training allocated

No inclusion but

sometimes depends No budget

on the donor allocated

requirement

1 Technical staff

with $\mathrm{PhD}$ and Gender issues Budget

trained in

inclusion

allocation in

place 
streaming gender in project catchment areas so far is not promising due to lack of expertise to mainstream gender. Gender mainstreaming is still a challenge since staffs with knowledge of gender related issues lack mainstreaming skills and this observation calls upon the efforts to train the staffs to enhance them with skills to mainstream gender and eventually be part and parcel of project activities.

\subsubsection{Inclusion of Gender into Normal Routine of an Institution}

In all institutions involved in implementation of project activities, gender has been included in daily routine of the project activities. As indicated in table above in most cases gender is emphasized in activities which require group involvement for delivering trainings and other project deliverables. Since gender is more than involvement in group activities then more need to be done in term of looking on the outcomes of men and women participation which now requires mainstreaming skills which is lacking in most of the districts.

\subsubsection{Budget for Gender Related Activities}

Given that gender-related activities are often imbedded in a larger project component, in institutions implementing the project there is no specific budget allocations for gender related activities like training on gender issues among District Facilitative Teams except at the level of Project Coordination Unit. For sustainable inclusion of gender in SLM activities there is a need to have budget allocated to gender related activities to finance training sessions on gender sensitisation and benefits to both men and women.

\subsection{Traditional Natural Resource Management Institutions, Their Rules and Regulation}

Various traditional institutions involved in natural resource management exist. They have written and unwritten norms. These include Community Based Organizations who established written and unwritten norms, believes and values in guiding natural resources management in the project catchment areas in the region. Also there exist Village elders groups and women groups who are also found working on issues related to natural resource management like tree planting, beekeeping and terracing. The degrees to which these institutions are committed towards enhancing NRM depends on whether are registered or not. In most cases, these traditional institutions have been formally registered. The registration of these institutions is done either at district level by the community development department.

Besides the formal institutions, there are also traditional ones, whose capacity of traditional institutions to mainstream gender in the project is based on their ability to provide a room for both men and women to take part in restoring the productivity of land. The traditional institutions identified include: Community Based Organisations, Village elders' groups, women groups and religious associations working in a particular area on issues related to natural resource management like tree planting. The identified traditional institution working in project catchment areas have strengths in terms of creating strong unity among group members; committed members, registration status, possession of land and space for bee-keeping. They established according to rules with constitution and are recognition by community members.

There are various rules formally established governing traditional institutions of NRM implementing SLM project in the project catchment areas. Rules identified include, which also are written norms in their constitutions include:

1) Each one should participate in groups' activities particularly meetings and tree planting activities;

2) Each one should participate in cleaning and conserving water sources and other activities as may be determined by the group;

3) Each member of CBOs should plant trees in areas surrounding his/her house;

4) Each member is responsible in guarding surrounding environment from destruction;

5) Each member should be educating other community members on importance of environmental conservation;

6) No one is allowed to cut down trees without permission from local organs;

These rules and regulations, which are formally, approved by village Councils and Ward Government in project catchment areas in the region. For effective use of rules and regulations, all people who violate these rules and regulations are penalised. A total of TZS 10000.00 is instituted as a penalty to someone who is late or had not attended the meetings or found destroying trees and the surrounding environment. These values have been effective in guiding land degradation including forest in the Kilimanjaro Region.

The type of activity done by traditional institution depends on its geographical location. Those found near 
water sources are mainly involved in conservation of water sources such as planting trees around water sources. The surrounding community members are acting as watch dogs for those who carry out restricted production activities along water sources boundaries. Others do provide trees to schools and distribute to local people around for planting. Institutions found near forest reserves such as Rau Forest and those adjacent to forest maintained by KINAPA are involved in bee-keeping activities. These activities have several advantages including acting as source of food to the community and secondly, enhance people to value forests as a livelihood sources and source of income. Other groups that are not found near water sources engage in maintaining tree nurseries and bee-keeping on their farms.

\subsection{SLM-Related Policies and Extent to Which They Consider Gender}

A review of SLM-related policies is important to understand how different policies and legal frameworks integrated gender. As such different policies have been reviewed to meet the stated objectives. These policies and legal framework includes National Water Policy, National Irrigation Policy, Environmental Policy, Energy Policy, Forest Policy and National Community and Gender Empowerment Policy.

The National Water Policy was established in 1997 and revised in 2004. The policy recognises gender consideration in water supply as a vital aspect to be integrated in natural resource management in both urban and rural settings. It recognises the problem of inaccessibility of water to both women and men and calls for active and effective participation of women and men in water supply programs and their management. In addition, the policy recognises the need for proper institutional arrangements for the development and management of water resource by formation of Water User Associations and conservation groups in both rural and urban areas. It states the need for awareness raising, training and empowerment of women to actively participate at all levels in water programs, including decision making, planning, supervision and management. This shows that the National Water Policy highly recognizes gender considerations in water and related issues including conservation and involvement of both men and women in its conservation.

The National Forest Policy of Tanzania was formulated in 1998. The policy among others, recognises and encourages local communities to participate in forest activities. It clearly stipulates forest land and tree tenure rights be owned by both men and women (Policy Statement 39). Section 4.4.11 of the policy recognizes that "Gender inequality in land tenure has prevented women from owning land and women's involvement in formal decision making on resource management has been virtually non-existent despite the important role of women in forestry activities. This is a valid observation, and it applies to the Kilimanjaro region, where women hardly access and own land in the project areas in the region. Access to land is strategic area for intervention towards mainstreaming gender in SLM project. This will enable both women and men to increase their level of productivity in the region.

The National Environmental Policy of Tanzania was enacted in 1997. The policy recognizes that women are the natural resources managers in the society. Their knowledge, experience, and traditional skills in the management natural resources and households should be tapped for increased environmental action. However, the productive potential of women is impaired by the disproportionate burden they bear in the management of household consumption and production on account of gender division of labour. Emphasis of the policy is directed on literacy of women as a key element for the improvement of health, nutrition, and education in the family to ensure gender equity.

The National Energy Policy of Tanzania was enacted in 2003. The policy recognises the problems facing women and the need for integrating them in natural resource conservation including forest. Section 2 states that "Inferior energy practices, particularly among poor households in rural and semi-urban areas, are mainly affecting women. The search, collection, and use of fuel-wood are associated with heavy and often low-productive time-consuming work, mainly performed by women. The energy policy, therefore, introduces an institutional focus on improvements of rural and semi-urban energy practices in order to reduce women workload and to involve them in the problem solving and decision-making processes on energy issues. Women are under represented on the supply side of commercial energy. The involvement of women at all levels of the sector shall, therefore, be prioritized to better utilize available potential competence and capacity. Training and incentives for increased female participation as decision-makers at all levels need to be encouraged." Also, other supporting policy statements include:

1) Promote gender equality within the energy sub-sectors both on the demand and supply (Sect. 60); 
2) Facilitate education and training for women in all energy aspects (Sect. 61). Promote awareness on gender issues concerning men and women's social roles in the energy sector (Sect. 62); and

3) Promote awareness and advocacy on gender issues in the energy sector (Sect. 63).

The National Community and Gender Empowerment Policy of Tanzania was formulated in 2000. The policy is progressive and directs what needs to be done to tackle problems facing women and bring about gender equality in all sectors. The policy has put in place strategies that can help to raise the status of women in social economic and political arenas, but there is still much to be done for all sectors to attain gender equality. However, even though in its objectives, the policy stresses that there will not be laws that are gender discriminative either from the government or customs and traditions, the fact is, most laws recognize customary laws which are discriminatory to women. For example, the Law of Marriage Act, Revised 2002; the Land Act, 1999; and the Village Land Act, 1999. The challenge, therefore, remains in eliminating discriminatory customs and traditions and enabling women to have equal status with men from family to community and national levels.

The National Irrigation Policy of Tanzania was enacted in 2009. This policy recognizes that women play major roles in developing and practicing irrigated agriculture but are hampered by low level of social status in the community and inadequate access to productive resources and services. The policy provides tangible efforts to involve women to actively participate in irrigation development. It recognises gender sensitivity and mainstreaming in development projects through:

1) Encouraging a fair representation of both women and men in irrigators' organizations;

2) Promoting effective participation of both women and men in initiation, planning, implementation, operation and maintenance of irrigation schemes;

3) Facilitating awareness raising, training and empowerment of women to actively participate at all stages in irrigation development; and

4) Ensuring that women and vulnerable groups have equal access to water, land, productive resources and support services for irrigation development.

Implementation of these policies and guidelines are hardly evident in project catchment areas and more efforts are needed for integrating the gender sensitive issues identified. The national policies reviewed highly recognize the need of gender consideration in development projects and policy statements, but not SLM as such. This lack of recognition, in fact underpins the need to mainstream of gender into this SLM project.

\subsection{Opportunities for Mainstreaming Gender Sensitivity}

Opportunities, which need to be harnessed for effective mainstreaming gender into SLM activities exist. These include the following:

1) Awareness of roles, values and participation of men and women in project catchment areas and gender policy frameworks;

2) Existence of other institutions involving in natural resource management in the region. For example Pangani River Basin, SIDO, KINAPA, Higher Learning Institutions and the community at large;

3) Availability of forest reserve for bee-keeping;

4) Existence of environmental conservation groups and organization operating in project catchment areas, which support members;

5) Availability of donor funds to support SLM project implementation in the region;

6) Support from Regional, District, Ward and Village government offices;

7) Existence of registered community based organisation in project catchment areas in the region supporting SLM activities implementation; and

8) Existence of democratic decision in leadership selection and appointment in community based organisations implementing SLM activities in project catchment areas.

\subsection{Risks in Mainstreaming Gender}

Along with opportunities realized in SLM project execution there are number of risks associated with gender mainstreaming in SLM project activities in the highlands of the Kilimanjaro region. Key risks identified include:

1) Delay in disbursement of funds for SLM project activities from Donor,

2) Inadequate working tools

3) Poor participation of youth in project activities including leadership positions and production processes. 
The existence of opportunities has created improving income levels of residents as well as ensured environmental conservation. Though much has been done by the project implementation team, more efforts are needed to tape the existing opportunities for minimizing risks and ensuring gender integration and project up scaling and replicability.

\section{The Strategy for Mainstreaming Gender into SLM Activities}

The ultimate goal of mainstreaming Gender into SLM activities is to achieve gender equality in project operational activities that benefits both men and women in Kilimanjaro region. This section highlights strategic gender issues/problems SLM project activities in the region, key strategic goals, objectives, strategies, activities and benchmark indicators. Other areas include Implementation plan, budget and modalities for implementation, monitoring and evaluation.

\subsection{Gender Mainstreaming Issues in SLM Activities: Lessons}

The study shows different gender mainstreaming issues that provide opportunities for mainstreaming gender into the SLM project activities in Kilimanjaro region. These include:

1) Extent of involvement/participation of men and women in productive and domestic activities in the project catchment areas differs and thus reduces levels of productivity in the region;

2) Both men and women play a great role in SLM project activities implementation though some complain on working gears, relationships, and leadership positions exists;

3) Existence of unequal benefit and access to productive resources between men and women;

4) Specific gender needs of both men and women in SLM project activities differs in project catchment areas;

5) Limited extension skills and services in mainstreaming gender in SLM project activities;

6) Limited feedback and monitoring mechanism among institutions implementing SLM project and other interested stakeholders;

7) Limited capacity of institutions in mainstreaming gender in project areas.

To ensure gender mainstreamed in SLM project activities by the next five years (2014-2019), strategic goals, objectives, strategies, activities and indicators are established and described (Refer Appendix 1).

\subsection{Modalities of Gender Mainstreaming Strategy Implementation}

In achieving these objectives sustaining gender awareness which already exists towards achieving gender mainstreaming strategy towards achievement of SLM goals need to be emphasises. These should take consideration in different ways.

1) In fact the responsibility for implementing the gender strategy does not rest solely with women's organizations, they are natural vehicles for promoting gender equality at the local as well as the national level. Women’s organizations involvement in awareness campaign may help women to know their rights;

2) Involve socio-economic aspects in general, by having a focal person trained in gender mainstreaming in each district to support developing, implementing, and monitoring guidance and strategy on gender mainstreaming, in coordination with concerned staff and partners. Training, information, experience and support on gender advocates (both women and men) in local governments as well as local level need to be effective in pursuing gender interests in local government and local environmental governance. There is a high demand of elected officials and bureaucrats in local government to have access to the information they need to pursue environmental as well as gender responsive policy and programming.

\subsection{Monitoring and Evaluation}

Monitoring and Evaluation (M \& E) is designed to ensure effective and efficient implementation of the strategy and the sustainability of the intended impacts. The $M$ \& E is instituted as a review mechanism to monitor the progress and assess outcomes compared to the original objectives, activities and targets/indicators established in this strategy. While, monitoring refers to the tracking of the progress of implementation of this gender strategy, evaluation on the other hand, is critical and objective appraisal of the overall Gender Mainstreaming Strategy in the form of specific milestones of achievements stated in the Logical framework matrix (Refer Appendix 2). 


\subsubsection{Monitoring}

Monitoring of success and impact of the Gender mainstreaming strategy will be the overall responsibility of the Regional Administrative Secretariat (RAS) Office in collaboration with the Regional Technical Team in place. The office, in collaboration with the team, will periodically audit the implementation of the strategy. However, the Office and Coordinating Team shall be the accounting Officers responsible for:

1) Prepare and issue monitoring and reporting guidelines to all officials who will be involved in the implementation and audit exercise as approved RAS Office with technical backstopping with National Programme Coordinating Team. Specifically, a data collection instrument will have to be prepared. Furthermore, Table 8 and Table 9 give the formats for annual and semi-annual reports, respectively to be prepared by the implementing institutions of the SLM activities;

2) Monitoring and Evaluation roles and responsibilities to be played by the RAS office. The office shall prepare an annual report that closely translates the Gender Mainstreaming Strategy into their own targets with the expected level of funding for the immediate year. Each Implementing Institutions may prepare a team which can collect information related to the monitoring of inputs/activities and results once every six months.

\subsubsection{Evaluation}

There will be two types of evaluation of the Gender Mainstreaming Strategy. Once every two and half years using internal evaluators, and another one once every five years using an external evaluation team working with one internal evaluator not responsible for the implementation of the Strategy. In such it will be worthy that the regional office within the planning unit to train one member of staff and later be appointed to do the evaluation of the strategy.

\section{The Future Outlook}

The study shows different gender issues/problems and opportunities for mainstreaming gender in SLM activities as discussed in this paper. These issues and opportunities identified may be utilised to attain the strategic goal of mainstreaming gender in SLM project activities in Kilimanjaro region. These goals for mainstreaming gender in SLM activities include attain good governance in SLM activities implementation in project catchment areas and beyond. Other strategic goals include awareness creation and training on natural resource management, technological repositions and improving human resource at Regional, District and Village levels. These manifest a gradual process which required attaining the following at present and in future:

1) Enhance participation of both men and women;

2) Ensure transparency and leadership positioning with gender perspectives;

3) Enhance cooperation among Tradition institutions and other stakeholders involving in SLM project activities implementation;

Table 8. Proposed format for annual and semi-annual reports.

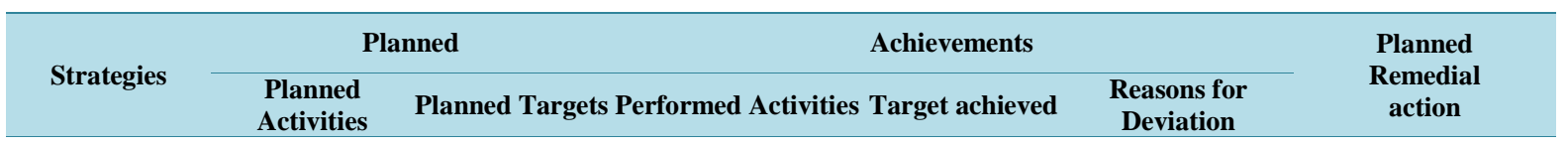

Table 9. Financial report on the implementation of the strategic. Plan for the period covering. name of the unit: 
4) Ensure timely disbursement of funds and transparency to members;

5) Integrating SLM activities in Gender Policies and legal framework;

6) Involvement of both CBOs members and community in project catchment areas;

7) Extension and mainstreaming skills attainment through training;

8) Formalisation of women and men equal participation in SLM project activities;

9) Data base management in place with best practices documentation;

10)Establishing a systematic feedback mechanism and monitoring systems;

11)Recruitment of more extension staff at regional and District Levels.

The role of women in environmentally-related activities in Kilimanjaro regional and elsewhere in Tanzania will be recognized and promoted with a view to achieving increased women's involvement and integration in all environmental management areas, the situation which SLM program highly attempted. For enhancing SLM project desired impact and sustainability, local institutions could be effective in engaging the energies and social relations of ordinary citizens and in increasing the willingness of the citizenry to participate in the movement. However, successful engagement with rural communities should start with recognizing that they have institutions through which they can practice or organize collective action for enhanced SLM objectives and activities.

Likewise, the concept of women empowerment concept of women has been emphasised in the policy document. Women are critical factor in the eradication of poverty and environmental conservation activities. The study concludes by arguing that gender mainstreaming is a long, slow process, requiring inputs of many institutions implementing the project as well as other stakeholder over a long period of time. It includes the need for collaborative synergies, and builds social relations to participate in SLM movement in the region, advocacy, advice and support, competence development, development of methods and tools and systematic follow-up, feedback and evaluation of progress. However, successful engagement with rural communities should not be under-emphasised and can start with recognizing that they have institutions through which they can practice and organize collective action for enhanced SLM activities implementation. Gender mainstreaming issues need to be recognised and shared across the system through documentation of the good practices and regular dialogue and consultation and thus gender mainstreaming strategy becomes feasible.

\section{Acknowledgements}

The authors of this paper benefited from various inputs made by different institutions and people to whom we are indebted and wish to thank towards making this research project real. First indepth thanks go to the Government of Tanzania, with support from the Global Environmental Facility (GEF) through UNDP for financial support to carry this study, without them it could have been impossible. Second the Kilimanjaro Regional Assistant Secretary, The Sustainable Land Management team and District Facilitating teams in the region for their valuable information platform sharing, draft document reviews and other logistic arrangements. Special thanks go to Dr. Fransis Mkanda, Mr. Damasi Masologo to mention a few for their technical expertise during the study. Further, we would like to thank Moshi University College of Cooperative and Business Studies management and staff for their valuable support. Mr. Edmund Zakayo, Gaudence Kapinga, Ms. Dorice Malisa and other field enumerators to mention a few deserve more thanks for their involvement in data collection and analysis. Moreover, Local communities in Rombo, Moshi Rural, Same, Siha, Moshi Urban and Mwanga District Councils in Kilimanjaro region deserved more thanks for sparing their time to share information during data collection phase. We thank you all.

\section{References}

[1] Mbilinyi, B.P., Tumbo, S.D., Mahoo, H.F. and Mkiramwinyi, F.O. (2007) GIS-Based Decision Support System for Identifying Potential Sites for Rainwater Harvesting. Elsevier Journal of Physics and Chemistry of the Earth, 32, 1074-1081.

[2] Moser, C.O.N. (1993) Gender Planning and Development: Theory, Practice, and Training. Routledge, London. http://dx.doi.org/10.4324/9780203411940

[3] United Nations (2005) Declaration and Platform for Action of the Fourth World Conference on Women. UN Division for Public Information UN, New York.

[4] Overholt, C., Anderson, M.B., Cloud, K. and Austin, J.E. (1985) Gender Roles in Development Projects: A Case Book. Connecticut, Kumarian Press. 
[5] Feldstein, H. and Jiggins, J. (1994) Tools for the Field: Methodologies Handbook for Gender Analysis in Agriculture. Kumarian Press, West Hartford.

[6] Narayan, D. (1996) Toward Participatory Research. World Bank Technical Paper No. 307. World Bank, Washington DC. http://dx.doi.org/10.1596/0-8213-3473-5

[7] World Bank (1996) Implementing the World Bank’s Gender Policies. Progress Report No.1. Washington D.C.

[8] FAO (2007) Climate Change in Agriculture, Forestry and Fisheries: Perspective, Framework and Priorities. Food and Agriculture Organization of the United Nations Rome.

[9] Kalipeni, E. (1992) Population Growth and Environmental Degredation in Malawi. Africa Insight, 22, $273-282$.

[10] Plane, D.A. and Rogerson, P.A. (1994) The Geographical Analysis of Populations with Applications to Planning and Business. Ch 2. John Wiley and Sons Inc., New York.

[11] United Republic of Tanzania (URT) (2012) Population and Human Settlements Census Report, Government Printers, Dar Es Salaam.

[12] Townsley, P. (1996) Rapid Rural Appraisal, Participatory Rural Appraisal and Aquaculture. Food and Agriculture Organization (FAO) Fisheries Technical Paper 358. FAO, Rome. 109 pp.

[13] Valentine, G. (1997) Tell Me About Using Interviews as a Research Methodology. In: Flowerdew, E. and Martin, D., Eds., Methods in Human Geography; A Guide for Students Doing a Research Project, Longman, London, 110-253.

[14] United Republic of Tanzania (URT) (1999) Land Act, Government Printers, Dar Es Salaam. 


\section{Appendices}

Appendix 1: Implementation plan and Budget.

GOAL No.1: Strengthen participation of men and women in both productive and domestic activities in project areas for enhanced natural resource management and poverty reduction by the year 2019 .

\begin{tabular}{|c|c|c|c|c|c|c|c|c|c|c|}
\hline \multirow[b]{2}{*}{ Objectives } & \multirow[b]{2}{*}{ Strategy } & \multirow[b]{2}{*}{ Activities } & \multirow[b]{2}{*}{ Indicators } & \multicolumn{4}{|c|}{ Level of attainment (Time frame) } & \multirow[b]{2}{*}{2019} & \multirow[b]{2}{*}{ BUDGET (Tshs) } & \multirow[b]{2}{*}{ ) Responsible Organ } \\
\hline & & & & 20142015 & 2016 & 2017 & 2018 & & & \\
\hline $\begin{array}{l}\text { mobilise equal } \\
\text { involvement of } \\
\text { men and women in } \\
\text { productive and } \\
\text { domestic activities } \\
\text { in project areas by } \\
\text { the year } 2018\end{array}$ & \multirow[t]{2}{*}{$\begin{array}{l}1.1 \text { Encourage } \\
\text { participation of } \\
\text { both women and } \\
\text { men for reduced } \\
\text { discrimination in } \\
\text { productive and } \\
\text { domestic } \\
\text { activities }\end{array}$} & $\begin{array}{l}\text { Maintaining gender } \\
\text { awareness of both } \\
\text { women and men in } \\
\text { project areas through } \\
\text { training including } \\
\text { gender rights and } \\
\text { related issues }\end{array}$ & $\begin{array}{l}\text { gender awareness of } \\
\text { both women and men in } \\
\text { project areas through } \\
\text { training including } \\
\text { gender rights and } \\
\text { related issues } \\
\text { maintained } \\
\text { (98\% as of present) }\end{array}$ & & & & & & $20,000,000$ & $\begin{array}{l}\text { SLM Regional } \\
\text { Coordination Office } \\
\text { and District Facilita- } \\
\text { tive Team }\end{array}$ \\
\hline & & $\begin{array}{l}\text { Ensuring equal access } \\
\text { and ownership of } \\
\text { productive resources }\end{array}$ & $\begin{array}{l}\text { equal access and } \\
\text { ownership of } \\
\text { productive resources to } \\
\text { both women and men } \\
\text { ensured by } 90 \% \text { in the } \\
\text { year } 2019\end{array}$ & & & & & & No fund required & $\begin{array}{l}\text { District } \\
\text { Facilitative Team }\end{array}$ \\
\hline \multirow{5}{*}{$\begin{array}{l}\text { No.1.2: To } \\
\text { establish systems } \\
\text { and structure for } \\
\text { leadership } \\
\text { appointment, } \\
\text { selection and } \\
\text { efficiency, which } \\
\text { accommodate both } \\
\text { women and men in } \\
\text { mainstreaming } \\
\text { gender in SLM } \\
\text { project activities }\end{array}$} & \multirow{5}{*}{$\begin{array}{l}\text { 1.2: Encourage } \\
\text { transparency and } \\
\text { commitment of } \\
\text { leaders and } \\
\text { institutions in } \\
\text { mainstreaming } \\
\text { gender }\end{array}$} & $\begin{array}{l}\text { Develop criteria for } \\
\text { leadership selection } \\
\text { including both } \\
\text { women and men } \\
\text { inclusion towards } \\
\text { mainstreaming gender } \\
\text { in SLM project } \\
\text { activities by the year } \\
2015\end{array}$ & $\begin{array}{l}\text { Criteria for leadership } \\
\text { selection in place by the } \\
\text { year } 2015\end{array}$ & & & & & & $5,000,000$ & $\begin{array}{l}\text { SLM Regional } \\
\text { Coordination Office } \\
\text { and District Facilita- } \\
\text { tive Team and Con- } \\
\text { sultant }\end{array}$ \\
\hline & & $\begin{array}{l}\text { Training on gender } \\
\text { mainstreaming skills } \\
\text { to institutions and } \\
\text { other interested stake- } \\
\text { holders in project area }\end{array}$ & $\begin{array}{l}\text { Training manual and } \\
\text { workshop } \\
\text { proceedings on } \\
\text { gender mainstreaming } \\
\text { skills in place by the } \\
\text { year } 2015\end{array}$ & & & & & & $15,000,000$ & $\begin{array}{l}\text { SLM Regional } \\
\text { Coordination Office } \\
\text { Consultants }\end{array}$ \\
\hline & & $\begin{array}{l}\text { Training on } \\
\text { leadership skills } \\
\text { towards } \\
\text { mainstreaming } \\
\text { gender in SLM Project }\end{array}$ & $\begin{array}{l}\text { Training manual and } \\
\text { workshop proceedings } \\
\text { on leadership training } \\
\text { in place by the year } \\
\text { t } 2015\end{array}$ & & & & & & $15,000,000$ & $\begin{array}{l}\text { SLM Regional } \\
\text { Coordination Office } \\
\text { Consultants }\end{array}$ \\
\hline & & $\begin{array}{l}\text { Establish a national } \\
\text { dialogue towards } \\
\text { formulation of SLM } \\
\text { policy, which } \\
\text { accommodates gender } \\
\text { mainstreaming }\end{array}$ & $\begin{array}{l}\text { At least two national } \\
\text { dialogue platforms and } \\
\text { proceedings on SLM } \\
\text { policy formulation in } \\
\text { place by the year } 2018\end{array}$ & & & & & & $15,000,000$ & $\begin{array}{l}\text { SLM Regional } \\
\text { Coordination Office }\end{array}$ \\
\hline & & $\begin{array}{l}\text { Up scaling and } \\
\text { enhancing } \\
\text { replicability of SLM } \\
\text { activities beyond the } \\
\text { Kilimanjaro project } \\
\text { catchment areas in the } \\
\text { region and elsewhere } \\
\text { in Tanzania }\end{array}$ & $\begin{array}{l}\text { Up scaling and } \\
\text { replicability strategies } \\
\text { for SLM activities } \\
\text { implemented developed } \\
\text { and implemented in } \\
\text { other areas by the year } \\
2019\end{array}$ & & & & & & $10,000,000$ & $\begin{array}{l}\text { SLM Regional } \\
\text { Coordination Office }\end{array}$ \\
\hline
\end{tabular}

GOAL No. 2: Capacity building to institutions implementing gender strategy in SLM project areas by the year 2019 


\section{Continued}

No.2.1: To

increase the 2.1: Institutional capacity of capacity institutions building in implementing mainstreaming SLM gender in activities in SLM project the region

\begin{tabular}{|c|c|}
\hline $\begin{array}{l}\text { Identify roles of } \\
\text { different actors in main- } \\
\text { streaming gender in } \\
\text { SLM project } \\
\text { activities }\end{array}$ & $\begin{array}{l}\text { Roles of different actors in } \\
\text { mainstreaming gender in } \\
\text { SLM project activities in } \\
\text { place by the year } 2015\end{array}$ \\
\hline $\begin{array}{l}\text { Conduct training on } \\
\text { gender mainstreaming } \\
\text { and project } \\
\text { sustainability to } \\
\text { institutions in } \\
\text { mainstreaming gender in } \\
\text { SLM project } \\
\text { activities }\end{array}$ & $\begin{array}{l}\text { A training manual and } \\
\text { workshop proceeding on } \\
\text { gender mainstreaming and } \\
\text { project sustainability to } \\
\text { institutions mainstreaming } \\
\text { igender in SLM project } \\
\text { activities in place by the } \\
\text { year } 2016\end{array}$ \\
\hline $\begin{array}{l}\text { Conducting } \\
\text { environmental } \\
\text { conservation } \\
\text { education and } \\
\text { training to target youth } \\
\text { below } 35 \text { years of age } \\
\text { for enhanced natural } \\
\text { resource conservation } \\
\text { and product use }\end{array}$ & $\begin{array}{l}50 \% \text { of youth below } 35 \\
\text { years of age trained on } \\
\text { environmental } \\
\text { education for enhanced } \\
\text { natural resource } \\
\text { conservation and product } \\
\text { use by the year } 2018\end{array}$ \\
\hline $\begin{array}{l}\text { Developing project } \\
\text { proposal for financial } \\
\text { mobilisation towards } \\
\text { implementing activities } \\
\text { related to gender } \\
\text { mainstreaming in SLM } \\
\text { project }\end{array}$ & $\begin{array}{l}\text { Sources of funds and at } \\
\text { least } 2 \text { project proposal } \\
\text { identities and developed } \\
\text { by the year } 2015\end{array}$ \\
\hline $\begin{array}{l}\text { Recruit adequate staff } \\
\text { with skills on gender } \\
\text { mainstreaming, } \\
\text { extension service, } \\
\text { monitoring, and project } \\
\text { evaluation and } \\
\text { sustainability in the } \\
\text { region }\end{array}$ & $\begin{array}{l}\text { Regular recruit and } \\
\text { appointment of SLM staff } \\
\text { and supporting facilitators } \\
\text { in the District Councils in } \\
\text { place }\end{array}$ \\
\hline
\end{tabular}

SLM Regional

No fund required Coordination Office

Consultants

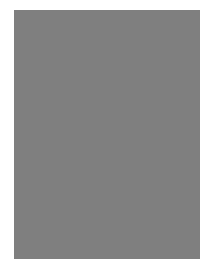

SLM Regional Coordination Office and

15,000,000 District Facilitative Teams

SLM Regional Coordination Office, District

15,000,000 Facilitative Teams and Traditional Institutions

SLM Regional Coordination Office

RAS Office

SLM Regional

15,000,000 Coordination Office

Goal No. 3: Enhanced monitoring and feedback mechanism for mainstreaming gender among institutions implementing SLM project and other interested stakeholders by the year 2019

Objectives Strategy

No.3.1: To

develop sys-

tem and

structure for 3.1: Encourage

structure for participatory

monitoring and ${ }_{\text {monitoring and }}^{\text {participatory }}$

feedback feedback

mechanisms in mechanism

gender in SLM

project 
W. Magigi, A. Sathiel

\section{Continued}

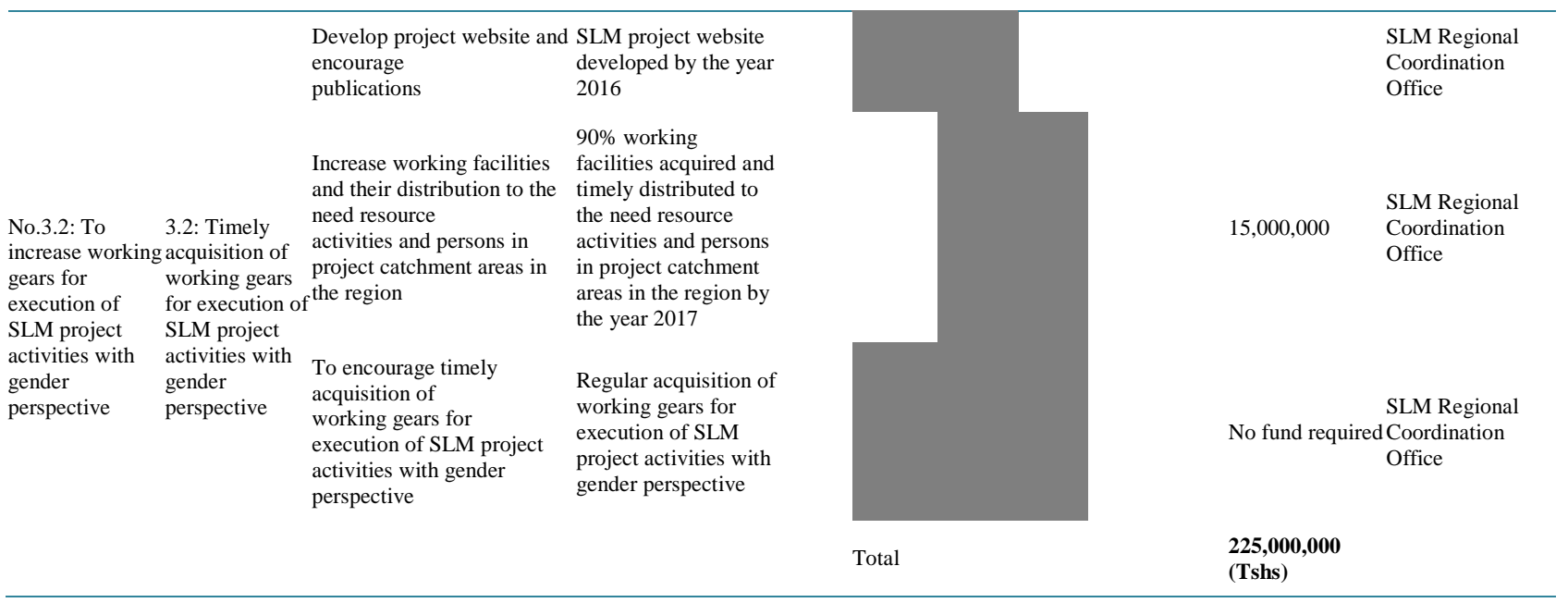


Appendix 2: Logical Framework Matrix.

\begin{tabular}{|c|c|}
\hline STRATEGIC GOAL & $\begin{array}{l}\text { STRATEGIC } \\
\text { OBJECTIVES }\end{array}$ \\
\hline $\begin{array}{l}\text { GOAL No. 1: } \\
\text { Strengthen } \\
\text { participation of men } \\
\text { and women in both } \\
\text { productive and } \\
\text { domestic activities in } \\
\text { project areas for } \\
\text { enhanced natural } \\
\text { resource management } \\
\text { and poverty reduction } \\
\text { by the year } 2019\end{array}$ & $\begin{array}{l}\text { No.1.1: To mobilise equal } \\
\text { involvement of men and } \\
\text { women in productive and } \\
\text { domestic activities in } \\
\text { project areas by the year } \\
2018\end{array}$ \\
\hline
\end{tabular}

No.1.2: To establish systems and structure for leadership appointment, selection and efficiency, which accommodate both women and men in mainstreaming gender in SLM project activities

\section{STRATEGY}

STRATEGY:

Encourage

participation of both women and men for reduced

discrimination in productive and domestic activities

\section{STRATEGY:}

Encourage

transparency and

commitment of lea

and institutions in

gender mainstreaming

\section{ACTIVITIES}

Sensitization of men and women on participation in both

productive and domestic activities participation in both productive and for sustained natural resource domestic activities by the year 2018 conservation and reduced poverty

Maintaining gender awareness of Gender awareness of both women and both women and men in project men in project areas through training areas through training including including gender rights and related issues gender rights and related issues maintained (98\% as of present)

Ensuring equal access and Equal access and ownership of ownership of productive resourcesproductive resources to both women and men ensured by $90 \%$ in the year 2019

Develop criteria for leadership Criteria for leadership selection selection including both women in place by the year 2015 and men inclusion towards

mainstreaming gender in SLM project activities by the year 2015

Training on gender mainstreaming skills to institutions and other interested stakeholders in project areas

Training on leadership skills towards mainstreaming gender in SLM Project

Establish a national dialogue towards formulation of SLM policy, which accommodates gender mainstreaming

Up scaling and enhancing replicability of SLM activities catchment areas in the region and year 2019 elsewhere in Tanzania

STRATEGY: Identify roles of different actors inRoles of different actors in mainstream- Availability of fund Institutional capacity mainstreaming gender in SLM ing gender in SLM project activities in building in project activities $\quad$ place by the year 2015

Capacity buildin institutions implementing gender activities in the region strategy in SLM project areas by the year 2019
ASSUMPTIONS

Willingness of both women and men

Willingness of institutions implementing the project place by the year 2015 and proceedings on SLM policy SLM activities implemented develope mainstreaming gender in SLM project

Conduct training on gender mainstreaming and project sustainability to institutions in mainstreaming gender in SLM project activities

Conducting environmental conservation education and training to target youth below 35 enhanced natural resource conservation years of age for enhanced natural and product use by the year 2018 resource conservation and product use

Developing project proposal for Sources of funds and at least 2 project financial mobilisation and institution budget allocation fo gender towards implementing activities related to gender mainstreaming in SLM project and district routine activities

Recruit adequate staff with skills Regular recruit and appointment of SLM on gender mainstreaming, extension service, monitoring, and project evaluation and sustainability in the region and implemented in other areas by the

Training manual and workshop proceedings on gender mainstreaming

Training manual and workshop proceedings on leadership training in

At least two national dialogue platforms formulation in place by the year 2018

Up scaling and replicability strategies for

A training manual and workshop proceeding on gender mainstreaming and project sustainability to institutions mainstreaming gender in SLM project activities in place by the year 2016

$50 \%$ of youth below 35 years of age Sources of funds and at least 2 project year 2015

Gender mainstreaming budget in seven district council in the region in place regularly staff and supporting facilitators in the District Councils in place 


\section{Continued}

\begin{tabular}{|c|c|c|c|c|c|}
\hline \multirow{8}{*}{$\begin{array}{l}\text { Goal No. 3: } \\
\text { Enhanced monitoring } \\
\text { and feedback } \\
\text { mechanism for } \\
\text { mainstreaming } \\
\text { gender among } \\
\text { institutions } \\
\text { implementing SLM } \\
\text { project and other } \\
\text { interested } \\
\text { stakeholders by the } \\
\text { year } 2019\end{array}$} & \multirow{6}{*}{$\begin{array}{l}\text { 3.1: To develop system } \\
\text { and structure for } \\
\text { monitoring and feedback } \\
\text { mechanisms in } \\
\text { mainstreaming gender in } \\
\text { SLM project }\end{array}$} & \multirow{6}{*}{$\begin{array}{l}\text { Encourage } \\
\text { participatory } \\
\text { monitoring and } \\
\text { feedback mechanism }\end{array}$} & $\begin{array}{l}\text { Establish gender disaggregated } \\
\text { data base in SLM activities }\end{array}$ & $\begin{array}{l}\text { Gender disaggregated data base in } \\
\text { SLM activities in place by the year }\end{array}$ & \multirow[t]{6}{*}{ Availability of fund } \\
\hline & & & $\begin{array}{l}\text { Regular Updating SLM project } \\
\text { activities inputs, outputs and } \\
\text { results }\end{array}$ & $\begin{array}{l}\text { Regular updating SLM project } \\
\text { activities inputs, outputs and results }\end{array}$ & \\
\hline & & & $\begin{array}{l}\text { Develop system for information } \\
\text { sharing and reporting to different } \\
\text { stakeholders }\end{array}$ & $\begin{array}{l}\text { System for information sharing and } \\
\text { reporting to different stakeholders in } \\
\text { place }\end{array}$ & \\
\hline & & & $\begin{array}{l}\text { Acquisition of computer software } \\
\text { and hardware for District } \\
\text { facilitating teams for SLM data } \\
\text { base management }\end{array}$ & $\begin{array}{l}7 \text { computer and software packages } \\
\text { for District facilitating teams } \\
\text { implementing SLM activities acquired } \\
\text { by the year } 2015\end{array}$ & \\
\hline & & & $\begin{array}{l}\text { Conduct training on computer } \\
\text { data base management systems }\end{array}$ & $\begin{array}{l}\text { Computer data base management skills } \\
\text { and competence developed to } \\
\text { institutions implementing SLM } \\
\text { activities by the year } 2017\end{array}$ & \\
\hline & & & $\begin{array}{l}\text { Develop project website and } \\
\text { encourage publications }\end{array}$ & $\begin{array}{l}\text { SLM project website developed by the } \\
\text { year } 2016\end{array}$ & \\
\hline & \multirow[t]{2}{*}{$\begin{array}{l}\text { 3.2: To increase working } \\
\text { gears for execution of } \\
\text { SLM project activities } \\
\text { with gender perspective }\end{array}$} & \multirow[t]{2}{*}{$\begin{array}{l}\text { Timely acquisition of } \\
\text { working gears for } \\
\text { execution of SLM } \\
\text { project activities with } \\
\text { gender perspective }\end{array}$} & $\begin{array}{l}\text { Increase working facilities and } \\
\text { their distribution to the need } \\
\text { resource activities and persons in } \\
\text { project catchment areas in the } \\
\text { region }\end{array}$ & $\begin{array}{l}90 \% \text { working facilities acquired and } \\
\text { timely distributed to the need resource } \\
\text { activities and persons in project } \\
\text { catchment areas in the region by the } \\
\text { year } 2017\end{array}$ & \multirow[t]{2}{*}{ Availability of fund } \\
\hline & & & $\begin{array}{l}\text { To encourage timely acquisition } \\
\text { of working gears for execution } \\
\text { of SLM project activities with } \\
\text { gender perspective }\end{array}$ & $\begin{array}{l}\text { Regular acquisition of working gears } \\
\text { for execution of SLM project activities } \\
\text { with gender perspective }\end{array}$ & \\
\hline
\end{tabular}

